\title{
Expectations for success: Auditing opportunities for students with print disabilities to fully engage in online learning environments in higher education
}

\author{
Melissa Cain \\ Australian Catholic University \\ Melissa Fanshawe \\ University of Southern Queensland
}

\begin{abstract}
The rapid digitalisation of learning has had demonstrable impacts on access to education for students with a print disability. In higher education contexts, learning management systems (LMS) have become the predominant method for distributing content. This conceptual article addresses how students with print disabilities such as vision impairment, blindness, dyslexia, and visual fatigue experience their education through online engagement. Using Redmond et al.'s (2018) online engagement framework for higher education, the authors analyse the cognitive, social, emotional, behavioural, and collaborative needs and expectations of these learners. This article provides a contemporary picture of the barriers students with print disabilities currently encounter and the possibilities for access available through the use of accessible and assistive technologies. Recommendations for equitable access, including a range of actionable strategies, are provided to assist teacher educators, higher education providers, higher education disability support advisors, and LMS designers.
\end{abstract}

Implications for practice or policy:

- Barriers to equitable engagement in education experienced by students with print disabilities can be overcome by utilising the detailed recommendations in the audit tool developed by the authors.

- Higher education providers should consider the recommendations in this article to ensure they meet legislative requirements for inclusion and that students with print disabilities achieve social, academic, and emotional connectiveness in their education.

Keywords: online learning, equitable access, print disability, inclusion, connectiveness

\section{Introduction}

Over the past 20 years, online learning systems have become standard practice and an increasingly dominant method for distributing content in higher education. Gaining a university degree includes an unavoidable requirement to engage with digitalised content, both to gain theoretical knowledge and also for social participation. Students expect this when enrolling in courses that are delivered online, but many courses involve blended or multimodal study, and even courses that are fully face-to-face require students to engage with content and submit assessment using online learning management systems (LMS). In 2016, $13 \%$ of higher education students in Australia were enrolled on a multimodal basis, however, about " $45 \%$ of students enrolled reported doing half or more of their study online" (Norton \& Cherastidtham, 2018, p. 24).

More than $18 \%$ of Australian adults have a print disability (Vision Australia, 2019). According to the Copyright Act 1968, people with print disabilities include "a person without sight; a person whose sight is severely impaired; a person unable to hold or manipulate books or to focus or move his or her eyes; or a person with a perceptual disability" $(2.10$, p. 13$)$. The authors add to this definition the effects of visual fatigue, resulting from prolonged use of computers and screens on the eye's continual need for adjustment, which includes acute and long-term ocular injury, "eye-strain, tired eyes, irritation, burning sensations, redness of eyes, dry eyes, blurred, and double vision" (Bali et al., 2014, p. 61). Students with dyslexia also have difficulty accessing print as the neurological condition causes difficulty interpreting the order of letters in words, as well as affecting memory and speed of processing necessary for literacy acquisition (Pang \& Jen, 2018). 
As with all formal educational contexts in Australia, higher education learning environments are designed for those who can see (Armstrong, 2009). As such, students with a print disability face barriers in equitably accessing the full university experience. In practice, this requires both "equal access to technology, as well as to educators who have the training to implement digital solutions" (Becker et al., 2018, p. 30). A recent study by Vision Australia reports:

[A]larming evidence that many university students who are blind or have low vision experience significant - and in some cases insurmountable - barriers due to insufficient accessibility of various online learning platforms that are now the mainstay of tertiary education. (2018, p. 2)

This conceptual article provides an examination of the common barriers to access and specific strategies to promote engagement in all areas of the university experience. Redmond et al.'s (2018) online engagement framework for higher education has been identified as the most suitable framework for auditing engagement experiences for students with print disabilities in higher education. Its five elements, social, cognitive, behavioural, collaborative, and emotional, align closely to the work of Cain and Fanshawe (2019a, 2020) which analyses the learning needs and expectations of students with a print disability in mainstream education contexts. This article will audit digital access and participation experiences for students in higher education with a print disability and make practical and actionable recommendations for higher education providers. A review of literature around legal and ethical requirements for equity of access, accessibility to online learning for students with a print disability, student engagement in online learning, and access to learning through assistive technologies is included, to provide context to this analysis and the consequent recommendations.

\section{Literature review}

\section{Legal and ethical requirements for equity of access}

Access to education is a human right and a social justice issue (Becker et al., 2018). Article 13 of the International Covenant on Economic, Social and Cultural Rights (United Nations General Assembly [UNGA], 1966) states that "higher education shall be made accessible to all" (Part 3). In Australia, the Tertiary Education Quality and Standards Agency's (TEQSA) Higher Education Standards Framework sets out "quality of educational experiences that students should expect" (Australian Government Tertiary Education Quality and Standards Agency [TEQSA], 2017, p. 9). Tertiary institutions must demonstrate that learning resources "are appropriate to the level of the course of study, consistent with the expected learning outcomes and modes of participation, and accessible when needed (including for individuals with special needs)" (Domain 3.3, p. 22). There are also legal and ethical requirements for higher education providers to ensure equity of access. Key national policies such as the Disability Discrimination Act 1992 and the Disability Standards for Education 2005 support equitable access to mainstream learning environments for students with a disability on the same basis as their peers.

The digitalisation of content and services has resulted in numerous benefits for students with a print disability such as the reduction of social barriers and promotion of knowledge sharing through use of the internet (Akcil, 2018). Nevertheless, such students experience a range of accessibility challenges and barriers. Research by Cain and Fanshawe (2019a) reveals that students with print disabilities come to the learning space with their own solutions but can be hindered by educators' inability or unwillingness to provide adjustments, which has "flow-on effects in hindering their full participation in society" (Harpur \& Suzor, 2013, p. 748).

Important international developments to support equitable access, such as those noted in the United Nations General Assembly (UNGA) Convention on the Rights of Persons with Disabilities (2007), and the Marrakesh Treaty to Facilitate Access to Published Works for Persons who are Blind, Visually Impaired or Otherwise Print Disabled (World Intellectual Property Organization [WIPO], 2013). The Guidelines on Information Access for Students with Print Disabilities (Australian Vice-Chancellors' Committee [AVCC], 2004) also assist to promote and represent best practice for universities in Australia. The guidelines state that "it is standard practice for all University departments to be able to provide materials in accessible format" and that "staff have access to advice and assistance on the creation of documents which can be made accessible to students" (AVCC, 2004, p. 3). 
Disability support advisors in higher education institutions provide guidance around issues of access for students and teaching staff. This may include the use of assistive technologies and alternative print formats. However, this is usually on an as needed basis and not as general professional development. It is clear that universities are obligated under the Disability Standards for Education to provide adequate training, "both to specialised support staff and to students who require specialised equipment" (Vision Australia, 2018, p. 30). The Guidelines on Information Access for Students with Print Disabilities recommend that staff are suitably trained in "course design and accessible teaching practices" (AVCC, 2004, p. 9). However, in practice, tertiary teachers have little knowledge or training around accessibility requirements for students with print disabilities (Brown et al., 2013).

The casualisation of the higher education workforce plays a role in limiting the effective distribution of information. TEQSA states that "unusually high reliance on casual staff poses risks for the quality of the student experience" (TEQSA, 2017, p. 28). In many universities in Australia, casually employed academics constitute the majority of the academic workforce (Norton \& Cherastidtham, 2018) and do not access continuing professional development. This presents a significant issue with disseminating knowledgeable about print disabilities and an understanding of "accessibility of the software that they require their students to use" (Vision Australia, 2018, p. 27). Systemic issues with staffing, professional development, and experience in making adjustments for students with a print disability provide barriers to access and successful educational outcomes academically and socially. To add depth to this issue, the following section provides a more nuanced examination of access to learning through LMS in higher education.

\section{Accessibility to online learning for students with a print disability}

University students with print disabilities typically encounter "significant accessibility barriers when using online learning environments", and in some cases these barriers "had resulted in participants abandoning their studies altogether, while others found studying extremely stressful, difficult and unrewarding" (Vision Australia, 2018, p. 4). Adaptive technologies and equipment can be used by students with disabilities to access the LMS. However, the ability for students to have equitable access to online content, assessment, and social interaction, will depend on their level of vision, their prior use of technology, and accessibility of content (Gentle et al., 2016). Advances in inbuilt accessibility tools and adaptive technologies such as voice recognition, screen reading, voice recording, podcasts, e-books, speech-based interaction with mobile phones, optical character recognition, and digital braille devices (Cain \& Fanshawe, 2019a) have increased opportunities for students with print disabilities to access online learning environments.

Students' prior experiences with technology and access to adaptive technologies will impact their levels of digital literacy and consequently their access (Akcil, 2018). Students known as digital natives (Prensky, 2001), predominately entering university as school leavers, usually have sufficient technology experience to access different formats of information online. Online learners however, tend to be "non-traditional students and are often adult learners who face competing demands, including family and work responsibilities" (Redmond et al., 2018, p. 185). Many adult learners with a print disability do not have the same ability to access print through adaptive technologies and may rely on printed braille, large print, or other accommodations to access course content.

Further, the design of the course needs to incorporate development of student identity by facilitating interaction with social and emotional elements of the course, to develop a feeling of belonging to the university (Redmond et al., 2018). All university students move through an acculturation process by immersing themselves into the student identity, negotiating academic expectations, ways of working in higher education, and a multitude of relationships. It is through this socialisation process that "people adopt and adapt to certain traditions, attitudes and values of a social group" (Barton et al., 2017, p. 2). Without access to these elements, people with print disabilities have barriers to full inclusion.

\section{Discussion}

\section{Student engagement in online learning}

Delivering courses online requires universities and academics to reconsider "how they can best utilise technology to support student learning" (Flavell et al., 2019, p. 1). Vision Australia suggests that "there 
appears to be little information available to universities about what constitutes best practice when meeting the needs of students" (2018, p. 19) who have print disabilities. Whilst many universities are using online learning as the predominant learning environment, the effectiveness of the educational experience context varies greatly (Deng \& Tavares, 2015; Weaver et al., 2008). According to Redmond et al. (2018) little attention has been devoted to assessing the quality of engagement for students engaged in online learning. Engagement can be defined as the extent to which students are connected to what they are learning, how they are learning it, and who they are learning from. Engagement is enhanced when students feel that the experience has value and relevance to their learning and their personal goals and needs.

In response to this gap in the existing documented knowledge, Redmond et al.'s (2018) online engagement framework for higher education is used as an "audit tool, or point of reference, when considering the types of engagement currently demonstrated by students" (Redmond et al., 2018, p. 196). The framework is particularly useful to evaluate engagement as it considers not only the cognitive impact interacting with course content, but also includes the behavioural, collaborative, emotional, and social impacts which assist students in gaining a sense of belonging to the course and to help students develop an identify as university students. This framework aligns with and supports the work of Cain and Fanshawe (2019a, 2019b, 2020) who have analysed the needs and expectations of students with a print disability in mainstream educational settings and found that to ensure authentic inclusion in education, the multidimensional needs of the learner (academic, social, emotional, behavioural, and physical) must be addressed.

With a social constructivist perspective, the authors highlight that Redmond et al.'s (2018) framework is underpinned by the learning theory of connectivism, "a new learning theory for a digital age" (Tschofen \& Mackness, 2012, p. 124) characterised by four key principles: autonomy, connectedness, diversity, and openness. This form of learning theory acknowledges the connection to a range of online information sources and knowledge sharing through internet technologies, characterised by students seeking knowledge and making links. In constructing meaning, learners "interact, communicate and build connections with each other, and they explore new information using multiple information and communication technologies" (Vas et al., 2018, p. 1033). For students with a print disability to have digital equity, or access to the full university experience, they should not only have access to learning, but autonomy to do so. In the following discussion, multidimensional factors which impact access and educational outcomes for students with a print disability are examined using Redmond et al.'s (2018) online engagement framework for higher education (Figure 1) as an auditing tool. This section also provides recommendations developed by the authors to address components of online learning that can increase efficacy for students in gaining fulfilling engagement with their university studies (Table 1).

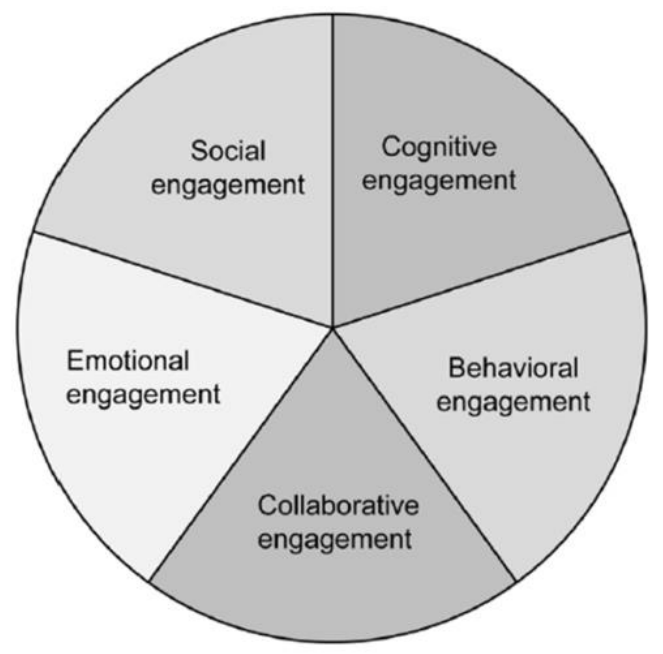

Figure 1. Online engagement framework overview (Redmond et al., 2018)

Alternate text: A circle divided into five equal parts of engagement; social, cognitive, behavioural, collaborative, and emotional. 


\section{Social engagement}

The ways in which students feel connectedness to their course is central for "developing deeper learning, [and] having collaborative experiences" (Ragusa \& Crampton, 2018, p. 217). Educators should focus on creating a sense of belonging "central for developing deeper learning, having collaborative experiences and increasing student retention rates" (Ragusa \& Crampton, 2018, p. 127). Higher education in Australia has high attrition rates for students with disabilities, in particular, for those with print disabilities (Vision Australia, 2018). Students with a print disability strive to be seen as the same as their peers, and whilst their disability is part of their identity, it is not primary to it (Cain \& Fanshawe, 2019b). Interestingly, where the online experience may be construed by some as isolating and impersonal (Thomas et al., 2014) it is often viewed as advantageous by students with a print disability, as they develop an identity as a student first, with others not immediately aware of their disability. These observations underscore the need for academics to consider needs for social engagement and how the barriers that may exist for students with a print disability using platforms that are designed for those who can see. The following section provides specific and actionable advice for LMS designers and academics designing their courses.

Course design

For students to connect and engage socially with peers and lecturers in the course the LMS must first be accessible to all students (Wong, 2012). Each LMS will be designed differently by each teacher with a primary focus on visual appeal (Cain \& Fanshawe, 2019a), and assumption learners have sight. Naveh et al. (2012) propose that ease of navigation through the course is linked to student success and their satisfaction with university studies. The increasing importance for equitable digital access has seen great improvements in inbuilt adaptive technologies from many LMS providers. Accessibility, particularly within forums, needs to be compatible with screen readers and braille machines, and students must be capable of searching forums using shortcuts or virtual assistants. Screen readers have made progress in the navigation space by reading aloud the content of the screen using a mouse or tab controls on the keyboard or braille machine (Perkins School for the Blind, 2019).

Many teachers are unaware that using title and headings sections when creating word documents helps screen readers and braille devices to navigate quickly through documents through this tabbing process, which is the equivalent of scanning for a sighted user. For students who are blind, the use of a mouse will not be possible, and activities which rely on the use of a mouse (such as drag and drop activities and dropdown menus) will not be accessible. Shortcuts, which are keyboard commands such as control + E to open the search box, can assist with navigation for students. Virtual assistants such as Siri, Google Home, Alexa, and Cortana are becoming increasingly useful in simplifying the complex tasks previously done via drop down menus by enabling students to search and navigate the LMS independently through voice commands (Forbes, 2019).

Visual images, symbols, diagrams, and multimedia are difficult to access for students with a print disability (Rule et al., 2011). Providing alternate text is an expectation for all HTML web pages (Disability Compliance for Higher Education, 2017). When uploading an image to the LMS, there is an option to include alternate text or a description of the content of the image. Figure 1 provided information to enable the reader to access the diagram, whilst figure 2 shows an example of alternate text provided for an image. 


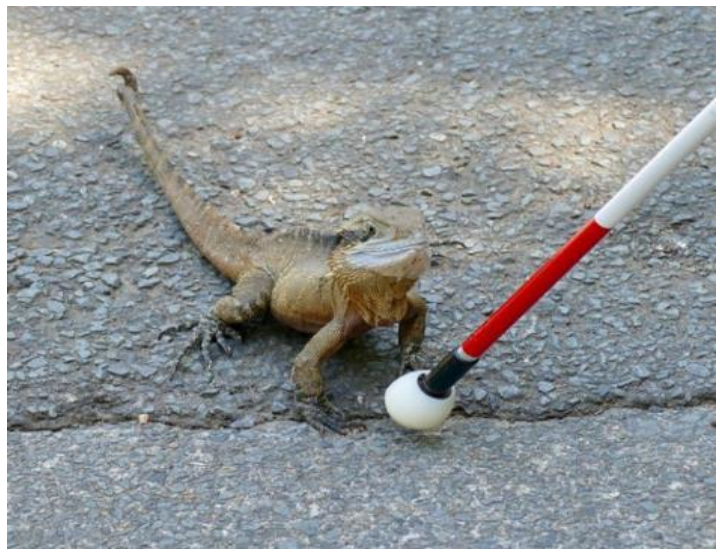

Figure 2. A baby frilly-necked lizard

Alternate text: A baby frilly-necked lizard on a concrete path. The frilly-necked lizard appears to be smiling and has stopped, looking up at a white cane, also on the path.

The alternate text not only describes the content of the image but informs the user of the function of the image through a semantic description. It is important that the alternate text is succinct, accurate, and equivalent to the visual content. Alternate text is also displayed if the image cannot be opened in the browser, which is important for all users in instances where the image will not load (Perkins School for the Blind, 2019).

All courses should be set out with clear visual style with a consistent font with easily distinguishable characters. According to the Round Table on Information Access for People with Print Disabilities (2011) Guidelines for Producing Clear Print, a default text size of 12 points should be used and should be well spaced and uncluttered, rather than written on background graphics. Text on both the LMS and within documents should be justified to the left, when possible, to enable the student to use magnification tools, screen readers, and braille machines to engage in the content independently.

\section{Social forums}

Social forums are often used to introduce students to each other at the beginning of the semester. Many students with print disability learn through the principles of social connectivism and rely on accessible opportunities to work together and socialise through online platforms. On-campus interactions where students with print disabilities are defined by their disability and access can be difficult due to the need to see body language, visual cues, and navigate through the classroom (Cain \& Fanshawe, 2019a). However online, students read information about each other and identities are created without a visual presence.

Opportunities for students to see their teachers and peers

Many lecturers provide live or recorded lectures and tutorials using web-based technologies (Chapin, 2018). Within these lectures, it is likely teachers will have a video image of themselves which is considered best practice to increase personal connection with online students (Thomas et al., 2014). When recording lectures and tutorials, teachers should use a clear voice that alters in pitch and expression to engage students who are listening. Slides shown in the background will be inaccessible to students with a print disability. As an alternative, the content of the slides can be read out by the teacher and/or uploaded as additional documents which can be accessed on the LMS.

\section{Cognitive engagement}

Cognitive engagement may be considered "the active process of learning" including "what students do and think to promote learning" (Redmond et al., 2018, p. 191). Inherent in this is a student's motivation, metacognition, self-regulation, and the values and goals they have for their learning. Students can be motivated to learn, but not necessarily engaged in a learning episode. According to Ryan and Deci (2000) autonomously motivated learners have a level of competence, connect with others, and have a sense of autonomy in their goals to see value and experience self-endorsement of their actions online. If the learner finds the content boring, irrelevant, distressing, too difficult or too easy, they may become cognitively 
disengaged. Educators invite cognitive engagement at both surface and deep levels through their design of structural elements such as lecture and tutorial slides, eBooks, and assessment. Cognitive engagement is important to successful achievement of learning outcomes for all students. This involves not only being able to engage with the content but also with the socioemotional aspects of learning which may not be front of mind for academics when considering how to devise their course sites. These factors are given attention in the following practical recommendations for learning design.

\section{Lectures}

In addition to live or recorded lectures, information may be provided as written modules, which allow students to work through the content at their own pace. Inbuilt LMS sources, such as eBooks, are accessible to students and compatible with adaptive technology. Having all eBooks available from the beginning of the course is particularly helpful for students with print disabilities as accessing content in enlarged print via screen readers, or braille, often takes additional time (Cain \& Fanshawe, 2019a). It is important to note that uploading a scanned picture of a document converted to PDF will not be accessible by screen readers and braille machines, and therefore, students will need to either try to find ways of scanning the document into an optical character recognition program (Buzzi et al., 2012) or request an accessible document from the teacher. Where PDFs need to be used (including presentations converted to PDF), an accessible format should be followed. This includes creating the document as searchable text, using clear font, and using navigational aids, such as page numbers and headings, to enable access by screen readers and braille devices (Adobe, 2012).

\section{Tutorials and breakout rooms}

Online tutorial sessions may present inequitable access, as there are a number of barriers for students who have a print disability. The layout of the online tutorial platform usually has many elements at once, such as video images of participants, slides or images, breakout rooms, and chat functions. Screen readers and braille machines are only able to tab to one element at a time, so students will not be able to access multiple objects simultaneously. Slides or PowerPoint images are not accessible when being viewed remotely and should be uploaded onto the LMS for students to access independently.

\section{Multimedia}

In conjunction with the advances in visual technologies "there has been a noticeable increase in the use of graphics, images, and animation in the presentation of e-learning materials" (Armstrong, 2009, p. 244). Multimedia objects, such as videos are often used to show how tasks are to be completed or explain topics with visual descriptions. Like images, the content and function of multimedia is unable to be accessed by people with print disabilities. An audio description or a "track of narration included between the lines of dialogue which describes important visual elements of a television show, movie or performance" (Ellis et al., 2016, p. 7) provides an opportunity for people with print disabilities to interact with multimedia. Due to technological advancements and consumer activation in this area, audio description is becoming more popular for television and movies (Ellis et al., 2016) and could also be useful in online learning.

\section{Course readings and textbooks}

Traditionally, students with print disabilities studying online have accessed course readings and textbooks through the disability support advisors by ordering printed braille or having the textbook recorded as an audio file. According to Harpur and Loudoun (2011) "technological advances have made it increasingly possible to provide students with print disabilities their textbooks in accessible formats" (2011, p. 154). Policy changes, such as the Marrakesh Treaty (WIPO, 2013), have also increased access to course materials which ratified the ability of people who have a print disability to have free access any printed works in an accessible digital format. Additional time may be required as "accessing course materials can take longer" (Vision Australia, 2018, p. 15) due to needing to use assistive technologies to access information and to navigate through the textbook.

\section{Assessment}

Researching and editing assessment tasks will take longer for students with print disabilities than their sighted peers due to the increased time to navigate between different online platforms and accessing library searches. Access to reference materials may be more difficult when navigational tools such as headers and page numbers are not included in readings and referencing can be time consuming. Adjustments for examinations may require large print, digital access, or scribes. Images, diagrams and graphs are difficult to gain full access as "interpretation bias can occur when images or pictures are described for a student and 
hidden information inferred by the pictures cannot be interpreted or easily conceptualised" (Cain \& Fanshawe, 2019a). When making accommodations for students with print disabilities, it is important to ask students what would work best to ensure access to fair and equitable testing (Disability Compliance for Higher Education, 2017).

\section{Behavioural engagement}

Behavioural engagement is concerned with attention, effort, persistence, and participation. From a behaviourist perspective, successful student engagement requires following procedures and expectations, that is "doing the work and following the rules" (Fredricks et al., 2004, p. 65). Some of the features of behavioural engagement in the online space have been described as "developing multidisciplinary skills, developing agency, upholding online learning norms, and supporting and encouraging peers" (Redmond et al., 2018, p. 193). The means by which teachers establish expectations for cognitive engagement is varied but must be given depth of thought to ensure students gain both surface knowledge and deep learning within the course. The relationship between students' behavioural engagement and their academic performance "is consistently statistically significant and repeatedly confirmed in empirical research" (Zanjani, 2017, p. 20). Explicit reinforcement of desired behaviours is important to help students develop academic skills and behaviours to be successful both within the course and as a university student.

\section{Getting started}

Setting course expectations at the beginning of the semester is an important part of assisting students with timelines and expectations, as well as showing them how to navigate efficiently through the course and access information (Naveh et al., 2012). Teachers can choose multiple ways to provide this information at the beginning of the course, including welcome videos with recorded tours of the study desk, and/or an announcement post with written communication describing the academic and social expectations in the course. For students with a print disability, recorded videos do not allow access to the visual material. However, teachers can verbalise the course expectations and process to explore the LMS.

\section{Weekly video/communication}

Weekly announcements or course updates help students to continually understand the teaching and learning environment and the expected timelines to complete course material (Wong, 2012). As students with print disabilities need more time to access and engage with learning materials, this is an important process as it helps students gain an understanding of what is expected in the near future as well as guidance to schedule desired learning outcomes. These can be presented as videos or written communication and teachers should verbalise any visual content in videos, consider uploading presentation slides and adhere to print accessibility formatting.

\section{Online norms}

In online environments, rules play "a significant part in mediating the overall transaction between individuals, the community and learning goals to be accomplished" (Wang, 2019. p. 5). Etiquette for engagement in forums are the most common guidelines provided on the LMS but other information about behavioural expectations, such as assessment guides, would also be useful for all students. Some of these are tacit expectations and not overtly emphasised. Therefore, it is important to ensure explicit modelling and feedback so students with a print disability are aware of expectations (Hullen, 2012).

\section{Behavioural analytics}

Learning analytics can be used to play an essential role in assessing course behaviours and initiating a feedback loop around student engagement within the course. Most LMS have inbuilt analytics which can be used to track students' progression through elements of the course. This information can track student progression, identify students who are at risk of not meeting expectations, and provide timely intervention through feedback. "Patterns and trends on how students interact with online course components" (Martin et al., 2016, p. 165) can also help teachers to inform improvements to the learning design. For students with print disabilities, learning analytics can be used to identify which course elements are not being accessed and initiate conversations with students to understand what adjustments students may need to access the course. 


\section{Collaborative engagement}

Collaborative learning involves students working together to accomplish shared goals. Positive interdependence motivates group members to help and support each other and remain engaged. When educators enhance collaborative learning strategies, they support students" willingness "to work cooperatively and productively with others with diverse learning and adjustment needs" (Gillies, 2014, p. 792) thus enhancing intergroup relations. The importance of collaboration in online learning is to help students create relationships with others and to feel the human element within the course (Garrison et al., 2001). For students with a print disability, involvement the socioemotional components of learning through collaborative engagement is contingent on being able to access and contribute group work tasks in a timely manner. Academics should give this priority when designing collaborative learning tasks so that true interdependence is possible.

\section{Collaborative forums}

Online forums and chat rooms have been shown to assist students to collaborate with their peers (Biasutti, 2017) by "constructing knowledge for one another, collaboratively creating a small culture of shared artefacts with shared meanings" (Moodle, 2019). Accessible online forums allow students to collaboratively work towards learning outcomes, including the provision and reception of feedback to each other throughout the course. Yet, discussion boards and collaborative tools are among the most difficult online platforms for students with print disabilities to access with assistive technology (Vision Australia, 2018). LMS providers need to continue to invest resources to provide accessible navigation (W3C Working Group, 2019).

\section{Teacher knowledge and attitudes}

Creating an accessible learning environment and inclusive culture throughout the university not only relies on the disability support officer, but also the student with disability, and indeed staff throughout the university. Every university educator must meet moral and legal obligations by creating accessible digital learning environments. What is concerning is that higher education institutions do not consistently meet the standards for digital accessibility and there is "no formal process to ensure that faculty and staff members complied with web accessibility policies" (Disability Compliance for Higher Education, 2017, p. 16). Moriarty (2007) highlights that "the most significant barriers to inclusivity in education being the lack of inclusive mindset, lack of knowledge about pedagogy, high teaching loads, and lack of time for instructional development" (p. 245). Despite many universities' mission and vision statements focus on inclusion, diversity and accessibility, many educators do not have the training to realise the functionality or tools that could be used to create more equitable opportunities for students. For successful full engagement in the university experience for students with a print disability, this needs to move from a declaration of support, to more formal, systemic promotion of practical solutions.

\section{Emotional engagement}

Emotional engagement within the framework, refers to the students" "emotional reaction to learning" (Redmond et al., 2018, p. 195). The aspects of cognition that are recruited most heavily in education "are both profoundly affected by emotions and in fact subsumed within the process of emotion" (ImmordinoYang \& Damasio, 2007, p. 7). This sector, therefore, interacts with cognitive learning and "can facilitate activation of attention and engagement" (Sinatra et al., 2015, p. 2) as emotions drive our interests, motivations, and engagement. These elements extend the online expectations to also include "participation in extracurricular or non-academic activities within the educational institution" (Redmond et al., 2018, p. 193). Emotional disengagement with the learning context often presents as withdrawal from the learning experience due to anxiety, boredom, frustration or apathy. Attrition rates for students with a print disability are significantly higher than for students without disability, and the unemployment rate for people with a vision impairment is 10 times the national average (Vision Australia, 2018). Finding an emotional connection to their studies can provide a student with print disabilities the confidence and desire to persist in solving issues of access and engagement and remain at university for the duration of their degree.

\section{Feedback throughout the course}

Continual feedback is a powerful generator of emotions and directly attributed to "student access, retention, completion, and satisfaction within college and university contexts" (Evans, 2013, p. 70). Individualised criterion-referenced and goal-directed feedback should be provided by both teachers and peers within 
forums, offering a platform for students to collaboratively engage in the feedback cycle, and increase emotional engagement in online learning (Wang, 2017). For students with print disabilities, however, receiving formative feedback can be difficult as some LMS plugins to grade assignments online and selfplagiarism tools are often not accessible. Audio feedback is an option to reduce barriers and provide full access to the feedback loop for students with print disabilities, and can be created through LMS assessment tools or recording an audio file on the teachers' mobile device, tablet or computer and uploading the file to LMS or sending it via email as an attachment (Woodcock, 2017).

\section{Unique requirements}

To engage a diversity of learners, it is very important to understand their individual differences and needs. Students vary in dispositions and capabilities, persistence, and mindset, which will impact their access to the digital learning environment (Bhagat et al., 2019). Students with print disabilities need to work harder to navigate LMS, magnify, listen to audio descriptions, and access the same content their sighted peers view visually (Harpur \& Loudoun, 2011). It is important that students with print disabilities have the emotional resilience to complete their studies and ask for assistance when needed. Teachers can monitor emotional engagement through learning analytics to monitor progression to identify opportunities to support learning.

\section{An audit tool for inclusive engagement for students with print disabilities}

With consideration of the five major factors facilitating online engagement (Figure 1), the authors have designed an audit tool for academics teaching students with print disabilities based on the components of Redmond et al.'s (2018) online engagement framework for higher education. The third column, Information components and the fourth column, Recommendations for improved practice, were added by authors. The information identifies elements that affect access for students with print disabilities within the online learning environment along with recommendations for improved practice.

Table 1

Audit of engagement factors for students with print disabilities in online learning

\begin{tabular}{|c|c|c|c|}
\hline $\begin{array}{l}\text { Online } \\
\text { engagement } \\
\text { element }\end{array}$ & $\begin{array}{l}\text { Indicators (illustrative } \\
\text { only) }\end{array}$ & Information components & $\begin{array}{l}\text { Recommendations for } \\
\text { improved practice (Cain \& } \\
\text { Fanshawe, 2021) }\end{array}$ \\
\hline $\begin{array}{l}\text { Social } \\
\text { engagement }\end{array}$ & $\begin{array}{ll}\text { - } & \text { Building community } \\
\text { - } & \text { beloating a sense of } \\
\text { - } & \text { Developing } \\
& \text { relationships } \\
\text { - } & \text { Establishing trust }\end{array}$ & $\begin{array}{l}\text { Course design - } \\
\text { drop down menus, } \\
\text { images, pictures and } \\
\text { diagrams, font and } \\
\text { formatting } \\
\text { - } \quad \text { Social forums } \\
\text { - Opportunities to see } \\
\text { teachers and peers }\end{array}$ & $\begin{array}{ll}\text { - } & \text { Adaptive technology - } \\
\text { screen readers, braille } \\
\text { machines, magnification } \\
\text { tools, virtual assistants } \\
\text { - } & \text { Shortcuts } \\
\text { - } & \text { Alternate text } \\
\text { - } & \text { Guidelines for } \\
\text { - } & \text { Accessible forums - } \\
\text { LMS providers } \\
\text { - Providing slides on } \\
\text { LMS }\end{array}$ \\
\hline
\end{tabular}




\begin{tabular}{|c|c|c|c|}
\hline $\begin{array}{l}\text { Cognitive } \\
\text { engagement }\end{array}$ & $\begin{array}{ll}\text { - } & \text { Thinking critically } \\
\text { - } & \text { Activating } \\
\text { - } & \text { Integracognition } \\
\text { - } & \text { Justifying decisions } \\
\text { - } & \text { Developing deep } \\
& \text { discipline } \\
\text { - } & \text { Disderstandings } \\
\text { Distributing expertise }\end{array}$ & $\begin{array}{ll}\text { - } & \text { Lectures } \\
\text { - } & \text { Tutorials and } \\
& \text { breakout rooms } \\
\text { - } & \text { Multimedia } \\
\text { - } & \text { Course readings and } \\
& \text { textbooks } \\
\text { - } & \text { Assessment } \\
\text { - } & \text { Assessment } \\
& \text { feedback }\end{array}$ & $\begin{array}{ll}\text { - } & \text { PDF accessibility } \\
\text { - } & \text { Providing slides on } \\
\text { - } & \text { AMS } \\
\text { - } & \text { Marrio description } \\
\text { - } & \text { Online access to } \\
\text { - } & \text { readings and textbooks } \\
\text { - } & \text { Additional time } \\
\text { - } & \text { Exam accossible documents } \\
\text { - } & \text { discussed with students } \\
\text { Audio feedback }\end{array}$ \\
\hline $\begin{array}{l}\text { Behavioural } \\
\text { engagement }\end{array}$ & $\begin{array}{ll}\text { - } & \text { Developing academic } \\
\text { skills } \\
\text { - } & \text { Identifying } \\
\text { opportunities and } \\
\text { challenges } \\
\text { - } \quad \text { Developing } \\
\text { multidisciplinary skills } \\
\text { - Developing learner } \\
\text { choice and agency } \\
\text { - Upholding online } \\
\text { - } \quad \text { Supporning norms } \\
\text { encouraging peer }\end{array}$ & $\begin{array}{ll}\text { - } & \text { Getting started } \\
\text { - } & \text { Intro video or } \\
\text { notices } \\
\text { - } & \text { Weekly } \\
& \text { announcements } \\
\text { - } & \text { Online guides } \\
\text { - } & \text { Personality traits of } \\
& \text { students }\end{array}$ & $\begin{array}{ll}\text { - } & \text { Verbalise course } \\
\text { - } & \text { Expectations } \\
\text { - } & \text { Explicit online norms } \\
\text { - } & \text { Learning analytics }\end{array}$ \\
\hline $\begin{array}{l}\text { Collaborative } \\
\text { engagement }\end{array}$ & 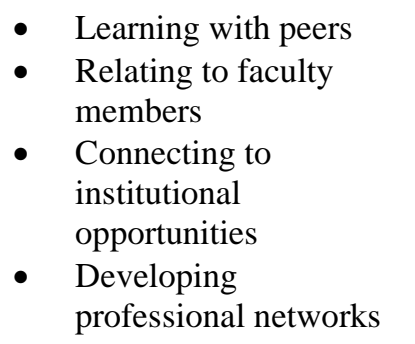 & $\begin{array}{ll}\text { - } & \text { Forums } \\
\text { - } & \text { Teacher knowledge }\end{array}$ & $\begin{array}{l}\text { - } \\
\text { - }\end{array} \begin{array}{l}\text { Communicate and } \\
\text { negotiate adjustments } \\
\text { - } \\
\text { Professional } \\
\text { development for staff }\end{array}$ \\
\hline $\begin{array}{l}\text { Emotional } \\
\text { engagement }\end{array}$ & $\begin{array}{ll}\text { - } & \text { Managing expectations } \\
\text { - } & \text { articulating } \\
\text { - } & \text { Recognising } \\
\text { motivations } \\
\text { - } \text { Committing to } \\
\text { learning }\end{array}$ & $\begin{array}{ll}\text { - } & \text { Feedback } \\
\text { - } & \text { Personality }\end{array}$ & $\begin{array}{ll}\text { - } & \text { Continual feedback } \\
\text { - } & \text { Positive mindset - } \\
& \text { students and lecturers }\end{array}$ \\
\hline
\end{tabular}

\section{Conclusion}

Students with print disabilities are being included in higher education learning in greater numbers. This has been the result of changes in policy and legal requirements in addition to greater awareness about the practical implications of accessibility. The digitalisation of content and development of assistive technologies has increased possibilities for access, but for students with a print disability, barriers and challenges remain. Using the five sectors of Redmond et al.'s (2018) online engagement framework for higher education the authors have made recommendations for simple changes that educators can make to their LMS and course design to enhance accessibility. These small changes have significant implications for the retention and satisfaction of students with a print disability. 
Integral to the effectiveness of such changes is the willingness of university teachers and staff to recognise the diversity of learning needs within their cohorts and a commitment to seek knowledge and solutions to overcome barriers. Vision Australia (2018) points to current practices as a systemic failure by the university sector to "develop and deploy online learning environments in ways that adequately address the needs of students who are blind or have low vision" (Vision Australia, 2018, p. 5). This need not be the case. Regular and up-to-date professional development and practical demonstrations of adjustments can work to uphold the International Covenant on Economic, Social and Cultural Rights' (UNGA, 1966) requirement that "higher education shall be made accessible to all" (UNGA, 1966, Article 13, Part 3). It is our legal, ethical, and moral responsibility to ensure learning environments are provided in an accessible format, to ensure all students with print disabilities have autonomy in learning, connectedness to knowledge and their peers, and openness in access in the true spirit of connectivism.

\section{References}

Adobe. (2012). Adobe acrobat xPro accessibility guide: Best practices for PDF accessibility. https://www.adobe.com/content/dam/acom/en/accessibility/products/acrobat/pdfs/acrobat-xi-proaccessibility-best-practice-guide.pdf

Akcil, U. (2018). The use of mobile learning for visually impaired learners school in tolerance education contents. Quality and Quantity, 52(2), 969-982. https://doi.org/10.1007/s11135-017-0552-1

Armstrong, H. (2009). Advanced IT education for the vision impaired via e-learning. Journal of Information Technology Education, 8, 243-256. https://doi.org/10.28945/691

Australian Government Tertiary Education Quality and Standards Agency (2017). Higher education standards framework. https://www.education.gov.au/standards-0

Australian Vice-Chancellors' Committee (2004). Guidelines on information access for students with print disabilities. https://www.adcet.edu.au/resource/5352/universities-australia-guide-information-accessfor-students-with-print-disabilities/

Bali, J., Neeraj, N., \& Bali., R. (2014). Computer vision syndrome: A review. Journal of Clinical Ophthalmology \& Research. 2(1), 61-68. https://www.jcor.in/text.asp?2014/2/1/61/122661

Barton, G., Hartwig, K., Bennett, D., Cain, M., Campbell, M., Ferns, S., Jones, L., Joseph, D., Kavanagh, M., Kelly, A., Larkin, I., O’Connor, E., Podorova, A., Tangen, D., \& Westerveld, M. (2017). Work placements for international students programs: A model of effective practice. In G. Barton, \& K. Hartwig, (Eds.), Professional learning in the work place for international students: Exploring theory and practice (13-34). Springer.

Becker, S. A., Brown, M., Dahlstrom, E., Davis, A., DePaul, K., Diaz, V., \& Pomerantz, J. (2018). NMC horizon report: Higher education edition. https://library.educause.edu/resources/2020/3/2020educause-horizon-report-teaching-and-learning-edition

Bhagat, K., Wu, L., \& Chang, C. (2019). The impact of personality on students' perceptions towards online learning. Australasian Journal of Educational Technology, 35(4), 98-108. https://doi.org/10.14742/ajet.4162

Biasutti, M. (2017). A comparative analysis of forums and wikis as tools for online collaborative learning. Computers \& Education, 111, 158-171. https://doi.org/10.1016/j.compedu.2017.04.006

Brown, C. M., Packer, T. L., \& Passmore, A. (2013). Adequacy of the regular early education classroom environment for students with visual impairment. Journal of Special Education, 46(4), 223-232. https://doi.org/10.1177/0022466910397374

Buzzi, M. C., Buzzi, M., \& Leporini, B. (2012). Investigating mobile learning and accessibility for blind learners. In M. Allegra, M. Arrigo, V. Dal Grande, P. Denaro, D. La Guardia, S. Ottaviano, \& G. Todaro (Eds.). Mobile learning for visually impaired people (pp. 26-40). https://giove.isti.cnr.it/AssetsSitoLab/publications/2012_a2_125.pdf

Cain, M., \& Fanshawe, M. (2019a). "Talk to me!": Empowering students with a vision impairment through audio e-assessment feedback. In C. Dann, \& S. O’Neill (Eds.), Technology-enhanced formative assessment practices in higher education (pp. 1-19). https://doi.org/10.4018/978-1-79980426-0

Cain, M., \& Fanshawe, M. (2019b). Opening eyes to vision impairment: Inclusion is just another way of seeing. In S. Carter (Ed.), Opening eyes onto inclusion and diversity (pp. 239-288). https://usq.pressbooks.pub/openingeyes/

Cain, M., \& Fanshawe, M. (2020). Catering for the specialised needs of students with vision impairment in mainstream classes: Listening to the students' voice for academic, physical and social inclusion. In 
S. O’Neill (Ed.), Inclusive theory and practice in special education (pp. 192-211). https://doi.org/10.4018/978-1-7998-2901-0

Chapin, L. (2018). Australian university students' access to web-based lecture recordings and the relationship with lecture attendance and academic performance. Australasian Journal of Educational Technology, 34(5), 1-12. https://doi.org/10.14742/ajet.2989

Copyright Act 1968 (Cth) (Austl.).

Deng, L., \& Tavares, N. J. (2015). Exploring university students' use of technologies beyond the formal learning context: A tale of two online platforms. Australasian Journal of Educational Technology, 31(3), 313-327. https://doi.org/10.14742/ajet.1505

Disability Compliance for Higher Education (2017). Blind and low-vision students. Disability Compliance for Higher Education, 22(6), 16. https://doi.org/10.1002/dhe.30265

Disability Discrimination Act 1992 (Cth) (Austl.).

Disability Standards for Education 2005 (Cth) (Austl.).

Ellis, K. M., Kent, M., \& Locke, K. (2016). Video on demand for people with disability: Traversing terrestrial borders. M/C Journal, 19(5), 1-3. https://doi.org/10.5204/mcj.1158

Evans, C. (2013). Making sense of assessment feedback in higher education. Review of Educational Research, 83(1), 70-120. https://doi.org/10.3102/0034654312474350

Flavell, H., Harris, C., Price, C., Logan, E., \& Peterson, S. (2019). Empowering academics to be adaptive with eLearning technologies: An exploratory case study. Australasian Journal of Educational Technology, 35(1), 1-15. https://doi.org/10.14742/ajet.2990

Forbes, M. (2019). Experiences of using intelligent virtual assistants by visually impaired students in online higher education [Unpublished doctoral dissertation]. University of South Florida, Tampa, FL.

Fredricks, J., Blumenfeld, P., \& Paris, A. (2004). School engagement: Potential of the concept, state of the evidence. Review of Educational Research, 74(1), 59-109. https://doi.org/10.3102/00346543074001059

Garrison, R., Anderson, T., \& Archer, W. (2001). Critical thinking, cognitive presence and computer conferencing in distance education. American Journal of Distance Education, 15(1), 7-23. https://doi.org/10.1080/08923640109527071

Gentle, F., Silveira, S., \& Gallimore, D. (2016). Vision impairment, educational principles and practice: Some fundamentals. RIDBC North Rocks Press.

Gillies, R., (2014). Cooperative learning: Developments in research. International Journal of Educational Psychology, 3(2), 125-140. https://doi.org/10.4471/ijep.2014.08

Harpur, P., \& Loudoun, R. (2011). The barrier of the written word: Analysing universities' policies to students with print disabilities. Journal of Higher Education Policy and Management, 33(2), 153-167. https://doi.org/10.1080/1360080X.2011.550088

Harpur, P., \& Suzor, N. (2013). Copyright protections and disability rights: Turning the page to a new international paradigm. UNSW Law Journal, 36(3), 745-778. https://ssrn.com/abstract=2335862

Hullen, J. (2012). The relevance of e-learning-accessibility for people with vision impairment. In M. Allegra, M. Arrigo, V. Dal Grande, P. Denaro, D. La Guardia, S. Ottaviano, \& G. Todaro (Eds.), Mobile learning for visually impaired people. https://giove.isti.cnr.it/AssetsSitoLab/publications/2012_a2_125.pdf

Immordino-Yang, M., \& Damasio, A. (2007). We feel, therefore we learn: The relevance of affective and social neuroscience to education. Mind, Brain, and Education, 1(1), 3-10. https://doi.org/10.1111/j.1751-228X.2007.00004.X

Martin, F., Ndoye, A., \& Wilkins, P. (2016). Using learning analytics to enhance student learning in online courses based on quality matters standards. Journal of Educational Technology Systems, 45(2), 165-187. https://doi.org/10.1177/0047239516656369

Moodle (2019). Philosophy. https://docs.moodle.org/36/en/Philosophy\#Constructionism

Moriarty, M. (2007). Inclusive pedagogy: Teaching methodologies to reach diverse learners in science instruction. Equity \& Excellence in Education, 40(3), 252-265. https://doi.org/10.1080/10665680701434353

Naveh, G., Tubin, D., \& Plisken, N. (2012). Student satisfaction with learning management systems: A lens of critical success factors. Technology, Pedagogy and Education, 21(3), 337-350. https://doi.org/10.1080/1475939X.2012.720413

Norton, A., \& Cherastidtham, I. (2018). Mapping Australian higher education report 2018. https://grattan.edu.au/report/mapping-australian-higher-education-2018/ 
Pang, L., \& Jen, C. (2018). Inclusive dyslexia-friendly collaborative online learning environment: Malaysia case study. Education and Information Technologies, 23(3), 1023-1042. https://doi.org/10.1007/s10639-017-9652-8

Perkins School for the Blind (2019). How to write alt text and image descriptions for the visually impaired. https://www.perkinselearning.org/technology/blog/how-write-alt-text-and-imagedescriptions-visually-impaired

Prensky, M. (2001). Digital natives, digital immigrants. Part 1. On the Horizon, 9(5), 1-6. https://doi.org/10.1108/10748120110424816

Ragusa, A., \& Crampton, C. (2018). Sense of connection, identity and academic success in distance education: Sociologically exploring online learning environments, Rural Society, 27(2), 125-142. https://doi.org/10.1080/10371656.2018.1472914

Redmond, P., Heffernan, A., Abawi, L., Brown, A., \& Henderson, R. (2018). An online engagement framework for higher education. Online Learning, 22(1), 183-204. https://doi.org/10.24059/olj.v22i1.1175

Round Table on Information Access for People with Print Disabilities (2011). Guidelines for producing clear print. http://printdisability.org/wp-content/uploads/2013/09/round table _clear_print_guidelines-\%20PDF.pdf

Rule, A., Stefanich, G., Boody, R., \& Peiffer, B. (2011). Impact of adaptive materials on teachers and their students with visual impairments in secondary science and mathematics classes. International Journal of Science Education, 33(6), 865-887. https://doi.org/10.1080/09500693.2010.506619

Ryan, R., \& Deci, E. (2000). Self-determination theory and the facilitation of intrinsic motivation, social development, and well-being. American Psychologist, 55(1), 68-78. http://selfdeterminationtheory.org/SDT/documents/2000_RyanDeci_SDT.pdf

Sinatra, G., Heddy, B. \& Lombardi, D. (2015). The challenges of defining and measuring student engagement in science. Educational Psychologist, 50(1), 1-13. https://doi.org/10.1080/00461520.2014.1002924

Thomas, L., Herbert, J., \& Teras, M. (2014). A sense of belonging to enhance participation, success and retention in online programs. The International Journal of the First Year in Higher Education, 5(2), 69-80. https://doi.org/10.5204/intjfyhe.v5i2.233

Tschofen, C., \& Mackness, J. (2012). Connectivism and dimensions on individual experiences. International Review of Research in Open and Distance Learning, 13(1), 124-143. https://doi.org/10.19173/irrodl.v13i1.1143

United Nations General Assembly (1966). International Covenant on Economic, Social and Cultural Rights, International Covenant on Civil and Political Rights, and Optional Protocol to the International Covenant on Civil and Political Rights. A/RES/2200.

United Nations General Assembly (2007). Convention on the rights of persons with disabilities: Resolution. A/RES/61/106.

Vas, R., Weber, C., \& Gkoumas, D. (2018). Implementing connectivism by semantic technologies for self-directed learning. International Journal of Manpower, 39(8), 1032-1046. https://doi.org/10.1108/IJM-10-2018-0330

Vision Australia (2018). Online but offtrack: Barriers to online learning experienced by university students who are blind or have low vision. https://www.visionaustralia.org/community/news/24-102018/online-but-offtrack

Vision Australia (2019). Print accessibility. https://www.visionaustralia.org/services/print-accessibility

W3C Working Group (2019). WAI_ARIA authoring practices 1.1. https://www.w3.org/TR/wai-ariapractices/\#no_aria better bad aria

Wang, F. (2017). An exploration of online behaviour engagement and achievement in flipped classroom supported by learning management system. Computers \& Education, 114, 79-91. https://doi.org/10.1016/j.compedu.2017.06.012

Wang, Y. (2019). How did graduate students of education major perceive ground rules in online discussions? Journal of Interactive Learning Research, 30(1), 5-25. https://www.learntechlib.org/primary/p/182167/

Weaver, D., Spratt, C., \& Nair, C. (2008) Academic and student use of a learning management system: Implications for quality. Australasian Journal of Educational Technology, 24(1), 30-41. https://doi.org/10.14742/ajet.1228

Wong, L. (2012). Students' attitudes towards e-learning: The first year accounting experience. Issues in Informing Science \& Information Technology, 9, 195-207. https://doi.org/10.28945/1616 
Woodcock, P. (2017). Towards dialogue: Audio feedback on politics essays. European Political Science, 16(2), 193-205. https://doi.org/10.1057/eps.2015.101

World Intellectual Property Organization (2013). Marrakesh treaty to facilitate access to published works for persons who are blind, visually impaired, or otherwise print disabled. https://www.wipo.int/publications/en/details.jsp?id=382\&plang=EN

Zanjani, N. (2017). The important elements of LMS design that affect user engagement with e-learning tools within LMSS in the higher education sector. Australian Journal of Educational Technology, 33(1), 19-31. https://doi.org/10.14742/ajet.2938

Corresponding author: Melissa Fanshawe Melissa.Fanshawe@usq.edu.au

Copyright: Articles published in the Australasian Journal of Educational Technology (AJET) are available under Creative Commons Attribution Non-Commercial No Derivatives Licence (CC BY-NC$\underline{\mathrm{ND}}$ 4.0). Authors retain copyright in their work and grant AJET right of first publication under CC BYNC-ND 4.0.

Please cite as: Cain, M., \& Fanshawe, M. (2021). Expectations for success: Auditing opportunities for students with print disabilities to fully engage in online learning environments in higher education Australasian Journal of Educational Technology, 37(3), 137-151. https://doi.org/10.14742/ajet.6449 